\title{
Resenha
}

\section{O QUE É EDUCAÇÃO?}

(BRANDÃO, Carlos Rodrigues. O Que é Educação? 33a Ed. São Paulo: Brasiliense 1995. Coleção Primeiros Passos. 116 p.)

Mônica Rocha Correia (1)

O autor inicia sua obra chamando atenção sobre uma carta em que os índios norteamericanos recusam a oferta de educação em escolas americanas para seus jovens, aos governantes de Virgínia e Mariland, após um tratado de paz. O contexto apresentado, a partir da carta, suscita diversas discussões sobre formas de educação e maneiras de fazer acontecer o processo educativo. O autor afirma que: a) existe a educação de um povo, de cada povo, e entre povos definindo-a de diversas maneiras; b) a educação é um dos meios de satisfação das necessidades dos homens; c) o educador pensa que age por si próprio, livre e em nome de todos, imaginando servir o saber a quem ensina.

O texto nos conduz a reflexão de que a educação pode acontecer em qualquer lugar, inclusive onde não há escola. Que por toda parte pode haver redes e estruturas sociais de transferência de saber de uma geração a outra, fazendo com que o homem crie suas próprias situações sociais de ensinar - aprender - ensinar.

Brandão afirma que, em alguns lugares, a educação é praticada de forma tão intensa que às vezes chega a ser invisível. Nas aldeias de muitos grupos tribais as crianças vêem, entendem, imitam e aprendem com a sabedoria que existe no próprio gesto de fazer as coisas. A transferência do conhecimento ocorre indistintamente por todos os membros do grupo, sendo a própria socialização a responsável pela transmissão do saber.

A educação tende a aparecer sempre que surgem formas sociais de condução e controle do ensino e, quando esta se sujeita a pedagogia, torna-se ensino formal, criando 
situações próprias para seu exercício, o quer inclui pessoas especializadas para o seu exercício. É quando aparecem escolas, alunos e professores.

Com o surgimento das escolas, o saber comum se desintegra. Surgem hierarquias sociais e a educação vira ensino que inventa a pedagogia, reduzindo o grupo à escola e transformando "todos" em educadores. Um novo saber, "mais elaborado" passa a ser transmitido desigualmente, promovendo as diferenças. O grupo reconhece neles por vocação ou por origem e, espera em cada um deles um trabalho especializado. Apesar disso, a rede de troca de saberes mais persistente e universal da sociedade humana é a família.

A educação elaborada na própria comunidade que reproduzia a igualdade entre os seus membros, agora passa a reproduzir a desigualdade social por sobre igualdades naturais - este sistema de ensino é originário da educação greco-romana. A Grécia é o berço da filosofia que permeia a conduta de nosso mundo ocidental. O autor, em breve referência histórica nos mostra que a separação das classes já existia no contexto da Grécia. Textos atribuídos a Solon 600 AC, orientam que as crianças devem antes de tudo aprender a nadar e a ler, e que os pobres devem exercitar-se na agricultura ou em uma indústria qualquer, ao passo que os ricos devem se preocupar com a música e a equitação e entregar-se a filosofia , a caça e a freqüência dos ginásios. Outro autor, Xenofonte $400 \mathrm{AC}$ ensinam que só os que podem criar os seus filhos para não fazerem nada é que os enviam as escolas; os que não podem não os enviam.

O autor trata ainda sobre a educação do jovem livre em escolas filosóficas sofistas e sobre a questão da "democratização do ensino" para os que podiam pagá-lo, enfocando que durante muitos séculos os pobres da Grécia aprendiam fora da escola, nas oficinas e nos campos, enquanto os meninos ricos, em acampamentos ou ao redor de velhos mestres.

A escola primária surgiu em Atenas por volta do ano 600 AC. O Pedagogo era um escravo que conduzia o aluno ao saber, no entanto é sobre a influência de Sócrates e de Epicuro que a educação começa a ser pensada como formadora do espírito, direcionando-a para a beleza do corpo e a clareza da mente. 
Com Carlos Magno, as escolas sofreram um novo impulso, e no avanço sobre os países dominados, a educação passa a estabelecer as relações de poder e legitimá-lo, inculturando o pensamento grego. Aprendemos dos gregos que a educação é fruto de todo meio sócio cultural sobre os seus participantes, isso é, o exercício de viver e conviver é que educa. A escola serve apenas de lugar provisório para que esta aconteça.

Em Roma o ócio não era bem vindo, a vida era austera, o culto aos antepassados era preservado, e o trabalho era exaltado. A educação era comunitária e os reis aravam terra junto com os seus servos, os filhos eram educados pela mãe até os sete anos e depois passavam a ser responsabilidade dos pais. Com enriquecimento da nobreza, estes passaram a preocupar-se com as regras do império, dividindo a educação em classes sociais, o Mestre escola vendia a educação como se fosse mercadoria em suas lojas de ensino dentro dos mercados.

O ensino primário de forma elementar surge no Século V aC. O Estado Romano não toma a seu cargo a tarefa de educar. A primeira escola pública só vai aparecer por volta do Século VI DC. A estrutura do ensino é manifestada sob a regência de Augusto e Libérius e fica assim definida : até os sete anos de idade - Doméstica, depois - loja de ensino (ludimagister). Aos doze anos - aulas de gramáticus e, aos dezesseis anos - aulas de Lector.

A educação em Roma segue por dois caminhos distintos: Uma Livresca, destinada aos futuros senhores e as Oficinas do trabalho, destinadas aos filhos dos Escravos, Servos e Artesãos. Da mesma forma como aconteceu na Grécia a escola em Roma também seguiu avançando junto com os Exércitos. Na prática, observa-se uma educação classista e a ausência da consciência de valores culturais mais consistentes.

Brandão avança tecendo críticas severas à educação no Brasil e a ação do estado, quando legisla com parcialidade, escondendo em suas ações as suas reais intenções, levando-nos a uma reflexão sobre a quem e para que serve a educação?

No caso, alguns filósofos acreditam que a educação é um meio pelo qual o homem desenvolve potencialidades biopsíquicas inatas, mas que não atingem a sua perfeição sem a aprendizagem realizada através da educação. 
O autor faz menção a diversos momentos históricos procurando definir a educação e sua origem. Chama atenção a ênfase dada a definição de Durkeim "A educação é a ação exercida pelas gerações adultas sobre as gerações que não se encontra ainda preparadas para a vida social, tem por objeto suscitar e desenvolver na criança certo numero de estados físicos, intelectuais e morais reclamados pela sociedade política no seu conjunto e pelo meio especial a que aquela criança, particularmente se destina ."

Pressupondo que o estado faz uso da educação para atingir seus interesses social ou de controle; a sociedade torna-se fundamentada em códigos sociais, regulamentados ou não pela lei. Dessa forma, a educação também passa a influenciar a vida e o crescimento da sociedade, em dois sentidos : 1- no desenvolvimento de suas forças produtivas; 2- no desenvolvimento de valores culturais, podendo sofrer variações diante de valores sociais novos, impossibilitando assim a existência de uma educação universal.

A educação torna-se dessa forma, um dos principais meios de realização de mudança social, podendo inclusive ser vista como um investimento, apesar de ainda ser uma promotora de desigualdades. Segundo o autor, normalmente a educação vem elaborada, de forma que nem os educandos nem mesmos os pedagogos e professores conseguem interferir nela. Isso reforça cada vez mais as desigualdades na sociedade brasileira.

Seguem-se os questionamentos por parte do autor: se a educação provoca desigualdades, porque então acreditar na educação? Brandão oferece como uma das respostas o fato da educação poder ser reinventada, sobre diversas formas " bancária, do oprimido, construtivista, entre outras", a educação poderia ser vista como uma verdadeira aventura humana. Existiria em toda parte, inclusive entre os opostos, assim como a vida é maior que a forma, a educação é maior que o controle formal sobre ela.

As classes subalternas recriam a educação de maneiras diversas, através de associações, sindicatos, comunidade de bairro, com manifestações culturais tipo bumba meu boi, capoeira, etc. e, retransmitem-na aos mais jovens, constituindo uma rede de transmissão do saber que, tornando-se mais resistente à invasão de outro saber; Neste caso, a esperança na educação se fundamenta em acreditar que o ato humano de educar existe tanto no trabalho pedagógico, quanto no ato político que se trava por um outro tipo de 
escola, por um outro tipo de mundo, a educação pode ser ao mesmo tempo: movimento e ordem, sistema e contestação.

Carlos Rodrigues Brandão é psicólogo formado pela PUC. Nascido em 1940 no Rio de Janeiro, mudou-se em 1966 para Brasília, tornando-se professor da Universidade Nacional de Brasília - UNB em 1967. Possui diversos títulos publicados pela editora Brasiliense.

(1) Mônica Rocha Correia é Advogada ambientalista e Pós-Graduada em Docência do Ensino Superior. E-mail: monicarochacorreia@uol.com.br 